\title{
New Indole Alkaloids from the Bark of Rauvolfia Reflexa and their Cholinesterase Inhibitory Activity
}

\author{
Mehran Fadaeinasab ${ }^{a}$ Alireza Basiri ${ }^{b}$ Yalda Kiac Hamed Karimian ${ }^{d}$ \\ Hapipah Mohd Alia Vikneswaran Murugaiyah ${ }^{b}$ \\ aDepartment of Chemistry, Faculty of Science, University of Malaya, Kuala Lumpur, biscipline of \\ Pharmacology, School of Pharmaceutical Sciences, Universiti Sains Malaysia, Penang, 'School of \\ Chemical Sciences, Universiti Sains Malaysia, Penang, 'Department of Pharmacy, Faculty of Medicine, \\ University of Malaya, Kuala Lumpur, Malaysia
}

\section{Key Words}

Rauvolfia reflexa - Indole alkaloids • Acetylcholinesterase • Butyrylcholinesterase • Dual inhibitor - Molecular docking

\begin{abstract}
Background/Aims: Rauvolfia reflexa is a member of the Apocynaceae family. Plants from the Apocynaceae family have been traditionally used in the treatment of age-related brain disorders. Methods and Results: Two new indole alkaloids, rauvolfine C (1) and 3-methyl10,11-dimethoxy-6-methoxycarbonyl- $\beta$-carboline (2), along with five known, macusine B (3), vinorine (4), undulifoline (5), isoresrpiline (6) and rescinnamine (7) were isolated from the bark of Rauvolfia reflexa. Cholinesterase inhibitory assay and molecular docking were performed to get insight of the inhibitory activity and molecular interactions of the compounds. The compounds showed good to moderate cholinesterase inhibitory activity with IC $_{50}$ values in the range of 8.06 to $73.23 \mu \mathrm{M}$. Compound 7 was found to be the most potent inhibitor of both acetylcholinesterase (AChE) and butyrylcholinesterase (BChE). Compounds 1, 2, 5 and 6 were found to be selective towards $B C h E$, while compounds 3, 4 and 7 were dual inhibitors, having almost equal inhibitory activity on both AChE and BChE. Molecular docking revealed that compounds 6 and 7 interacted differently on $A C h E$ and $B C h E$, by means of hydrophobic interactions and hydrogen bonding. In $\mathrm{AChE}$, the indole moiety of both compounds interacted with the residues lining the peripheral anionic site, whereas in $B C h E$, their methoxy groups are primarily responsible for the strong inhibitory activity via interactions with residues at the active site of the enzyme. Conclusion: Two new and five known indole alkaloids were isolated from $R$. reflexa. Among the compounds, 7 and 6 showed the most potent and promising cholinesterase inhibitory activity, worthy for further investigations.
\end{abstract}




\section{Cellular Physiology Cell Physiol Biochem 2015;37:1997-2011

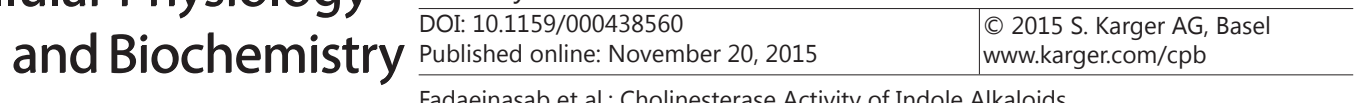

\section{Introduction}

Rauvolfia reflexa is a member of the Apocynaceae family. There are approximately 85 species of Rauvolfia, which are mainly found in tropical regions [1]. Rauvolfia species have been used as antidote for poisons and to treat malaria [2, 3]. Interestingly, plants from the Apocynaceae family have been traditionally used in the treatment of age-related brain disorders, such as Tabernaemontana heterophylla leaves, taken as tea for age related brain disorders including forgetfulness [3].

In dementia related brain disorders, in particular Alzheimer's disease (AD), there is impairment of cholinergic neurotransmission at cognitive related regions of the brain, resulting from deficiency of acetylcholine neurotransmitter [4]. A number of approaches were developed to enhance the cholinergic function in $\mathrm{AD}$ patients; the most clinically relevant has been the use of acetylcholinesterase (AChE) inhibitors that inhibit the degradation of the remaining acetylcholine [5, 6]. Many natural alkaloids have been studied for AChE inhibitory activity as potential candidate for symptomatic treatment of Alzheimer's disease. Various classes of alkaloids, in particular indole derivatives (such as physostigmine), isoquinoline derivatives (such as galanthamine and lycorine-type alkaloids), steroidal and terpenoid alkaloids have shown potent inhibitory effects on $\mathrm{AChE}[7,8]$. Plant families that are potential sources of such alkaloids include among others Amaryllidaceae, Buxaceae, Apocynaceae, Papaveraceae, Lycopodiaceae, and Leguminosae $[9,10]$.

The phytochemistry of the Rauvolfia species has been comprehensively investigated, in particular for the presence of alkaloids [9]. Previously, we reported the isolation of compounds from $R$. reflexa showing moderate AChE inhibition [11]. Herein, we describe the isolation and structural elucidation of two new along with five known indole alkaloids and evaluation of their cholinesterase inhibitory activity. Consequently, molecular docking investigation was undertaken to determine the molecular interactions between the inhibitory compounds and the enzymes.

\section{Materials and Methods}

Plant materials, enzymes and chemicals

Plant materials collection, enzymes and chemicals used for cholinesterase inhibitory assay were similar to those reported previously [11].

\section{General procedures}

Optical rotation was measured on Jasco P-1020 polarimeter (Japan). Column chromatography (CC) was run on silica gel 60 (40-63 $\mu \mathrm{m}$; Merck, Darmstadt, Germany). TLC was performed on aluminum and glass plates pre-coated with silica gel $60 \mathrm{~F}_{254}$ Merck (Darmstadt, Germany). Spots were visualized under UV light or by spraying with Dragendorff's reagent. Preparative HPLC was conducted using a Waters 2707 instrument (MA, USA) with a PDA 2998 detector Waters (MA, USA) and a C-18 Luna column $(250 \times 21.2$ $\mathrm{mm}, 5 \mu \mathrm{m} ; \mathrm{CA}, \mathrm{USA})$.

\section{Extraction and isolation of the alkaloids}

The bark of R. reflexa (1.0 kg) was extracted exhaustively with $5 \mathrm{~L}$ of $n$-hexane for 48 hours continuously by cold extraction method to remove the non-polar organic compounds, waxes and fats. The resulting residue was dried and re-extracted with methanol $(3 \times 10 \mathrm{~L})$. Upon removal of the solvents in vacuo, the methanol extract (20 g) was obtained. The presence of alkaloids was tested by using TLC technique and Dragendoff's reagent, which appear as orange spots. The methanolic extract (10 g) was fractionated using silica gel CC, eluted with dichloromethane- methanol $\left(\mathrm{CH}_{2} \mathrm{Cl}_{2} / \mathrm{MeOH}, 100: 0 \rightarrow 0: 100\right)$ to afford 8 fractions, $\mathrm{A}_{1}-\mathrm{A}_{8}$, pooled on the basis of TLC analysis. Fraction $A_{8}(1.2 \mathrm{~g})$ was chromatographed over silica gel $60(40-63 \mu \mathrm{m})$ eluted with dichloromethane-methanol $(100: 0 \rightarrow 0: 100)$ to give four sub-fractions, $A_{8} a-A_{8} d$. Separation of fraction $\mathrm{A}_{8} \mathrm{c}(0.35 \mathrm{~g})$ by preparative HPLC $\left(50-100 \% \mathrm{ACN}-\mathrm{H}_{2} \mathrm{O}\right.$, detection at $\left.210 \mathrm{~nm}, 7 \mathrm{~mL} / \mathrm{min}\right)$ successively, yielded $1(5 \mathrm{mg}), 2$ (6 mg) and $3(6 \mathrm{mg})$. Fraction $\mathrm{A}_{4}(1.3 \mathrm{~g})$ was chromatographed over silica gel $60(40-63 \mu \mathrm{m})$ eluted with dichloromethane-methanol $(100: 0 \rightarrow 0: 100)$ to give five sub-fractions, $\mathrm{A}_{4} \mathrm{a}-\mathrm{A}_{4} \mathrm{e}$. Fraction $\mathrm{A}_{4} \mathrm{~b}$ and $\mathrm{A}_{4} \mathrm{c}$ were combined $(0.51 \mathrm{~g})$ and purified by preparative TLC $\left(\mathrm{CH}_{2} \mathrm{Cl}_{2} / \mathrm{MeOH}, 87: 13\right)$ to yield 4 (8 $\left.\mathrm{mg}\right)$ 


\section{Cellular Physiology Cell Physiol Biochem 2015;37:1997-2011 \begin{tabular}{l|l|l}
\hline DOI: 10.1159/000438560 & (C) 2015 S. Karger AG, Basel
\end{tabular} \begin{tabular}{l|l} 
and Biochemistry Published online: November 20, 2015 & $\begin{array}{l}\text { क 2015 S. Karger AG, } \\
\text { www.karger.com/cpb }\end{array}$ \\
\hline
\end{tabular} \\ Fadaeinasab et al.: Cholinesterase Activity of Indole Alkaloids}

and 6 (7 mg). Fraction $\mathrm{A}_{5}$ (1.4 g) was chromatographed over a LH-20 sephadex column, using methanol as mobile phase to give five sub-fractions, $\mathrm{A}_{5} \mathrm{a}-\mathrm{A}_{5} \mathrm{e}$. Fraction $\mathrm{A}_{5} \mathrm{~d}$ was subjected to preparative $\mathrm{TLC}\left(\mathrm{CH}_{2} \mathrm{Cl}_{2} /\right.$ $\mathrm{MeOH}, 85: 15)$ to yield 5 (6 mg) and 7 (10 mg). The structures of the isolated alkaloids are shown in Fig. 1.

Cholinesterase inhibitory assay and molecular docking

Cholinesterase inhibitory activity and molecular docking studies were carried out as described by Fadaeinasab et al. [11].

\section{Results and Discussion}

\section{Structural elucidation}

Rauvolfine C (1) was isolated as a brownish amorphous solid; [ $\alpha] 24 \mathrm{D}^{24} \mathrm{D}-16(c$ 0.08, $\mathrm{CHCl}_{3}$ ). The HRESIMS at $\mathrm{m} / \mathrm{z} 325.1924[\mathrm{M}+\mathrm{H}]^{+}\left(\right.$calcd for $\mathrm{C}_{21} \mathrm{H}_{28} \mathrm{~N}_{2} \mathrm{O}$ ) (Fig. 2). The UV spectrum revealed maximum absorptions at 250 and $285 \mathrm{~nm}$, which were characteristic for a substituted indole chromophore [12]. The IR spectrum showed a band of $\mathrm{OH}$ group at 3378 $\mathrm{cm}^{-1}$. The ${ }^{1} \mathrm{H}$ NMR spectrum (Fig. 3) indicated the presence of three aromatic protons at $\delta$ $7.12(\mathrm{~d}, J=10.0,1 \mathrm{H}), \delta 6.83(\mathrm{~d}, J=2.3,1 \mathrm{H})$ and $\delta 6.73(\mathrm{dd}, J=8.7,2.2,1 \mathrm{H})$ attached to C-12, C-9 and $\mathrm{C}-11$, respectively. In the up field region, one singlet peak appeared at $\delta 3.79$, attributed to one methoxy group $(\mathrm{s}, 3.79,3 \mathrm{H})$. There were a total of twelve aliphatic proton signals observed in the ${ }^{1} \mathrm{H}$ NMR spectrum. Fourteen methylene proton signals appeared between $\delta 1.22-3.75$, which were due to the protons attached to C-5, C- $6, \mathrm{C}-14, \mathrm{C}-16, \mathrm{C}-17, \mathrm{C}-18$ and $\mathrm{C}-22$. The signal for another four aliphatic protons each at $\delta 3.20,1.54,1.30$ and 3.63 were assigned to H-3, H-15, H-20 and H-21, respectively. Finally a doublet in the up field region

Fig. 1. Chemical structures of the indole alkaloids isolated from the bark of Rauvolfia reflexa
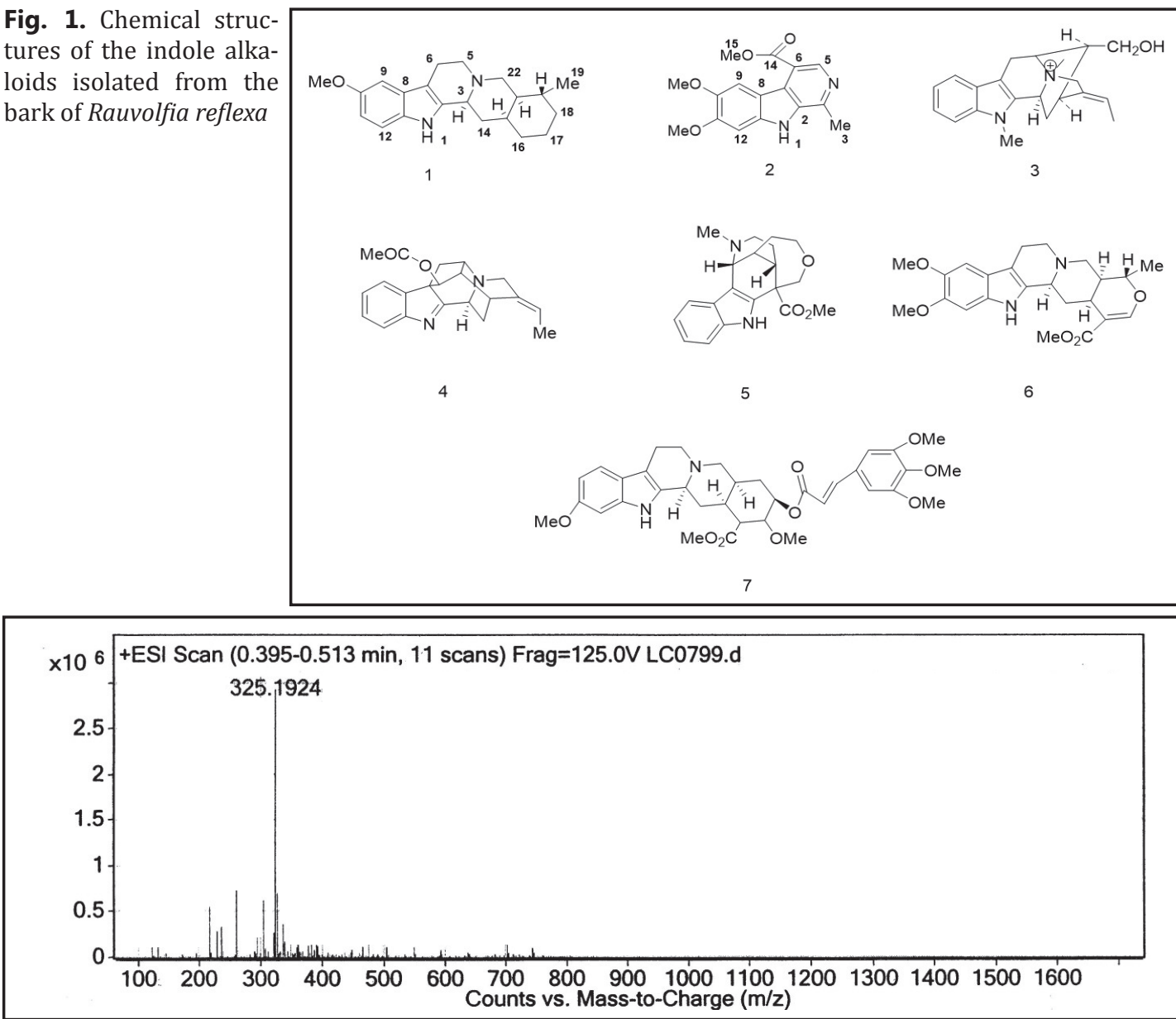

Fig. 2. Molecular weight of (1). 

Cellular Physiology Cell Physiol Biochem 2015;37:1997-2011 \begin{tabular}{l|l} 
DOI: 10.1159/000438560 & O 2015 S. Karger AG, Basel
\end{tabular} $\begin{array}{ll}\text { Published online: November 20, } 2015 & \text { www.karger.com/cpb }\end{array}$
Fadaeinasab et al.: Cholinesterase Activity of Indole Alkaloids

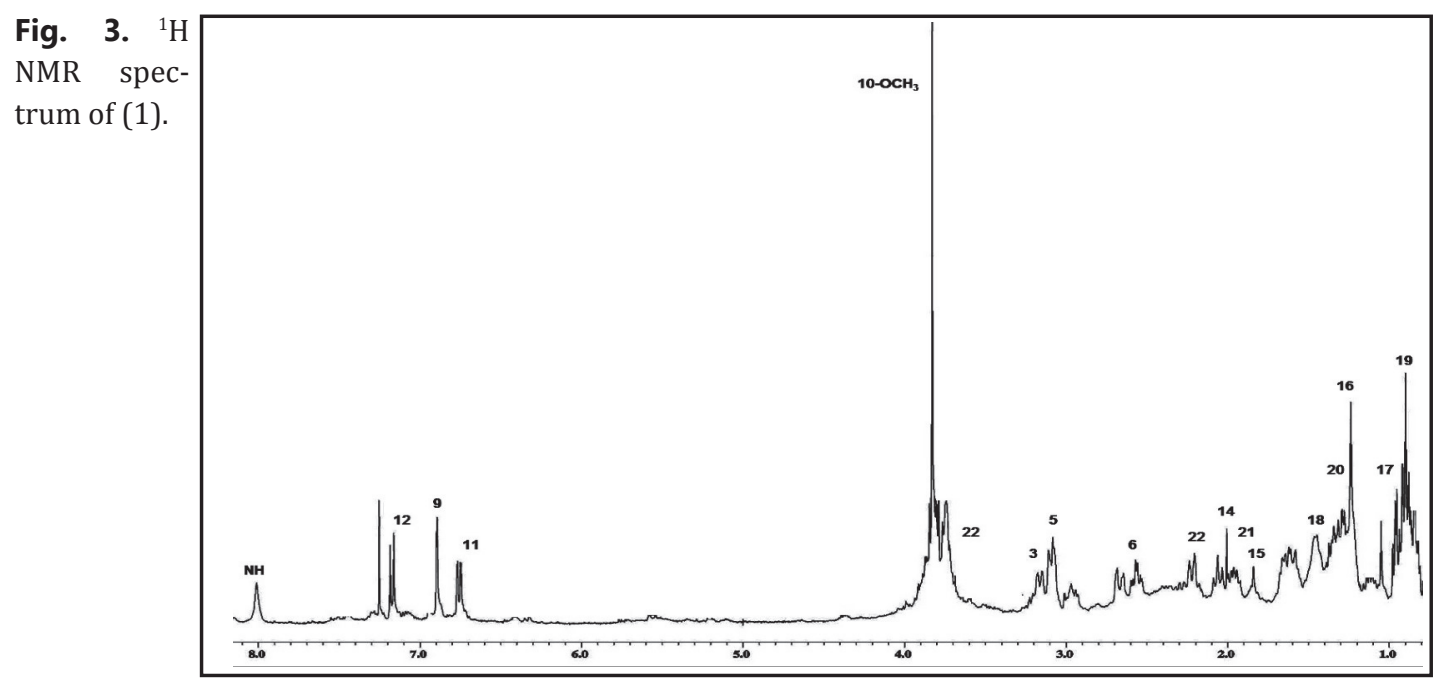

Fig. 4. ${ }^{13} \mathrm{C}$ NMR spectrum of (1).

Fig. 5. HSQC spectrum of (1).

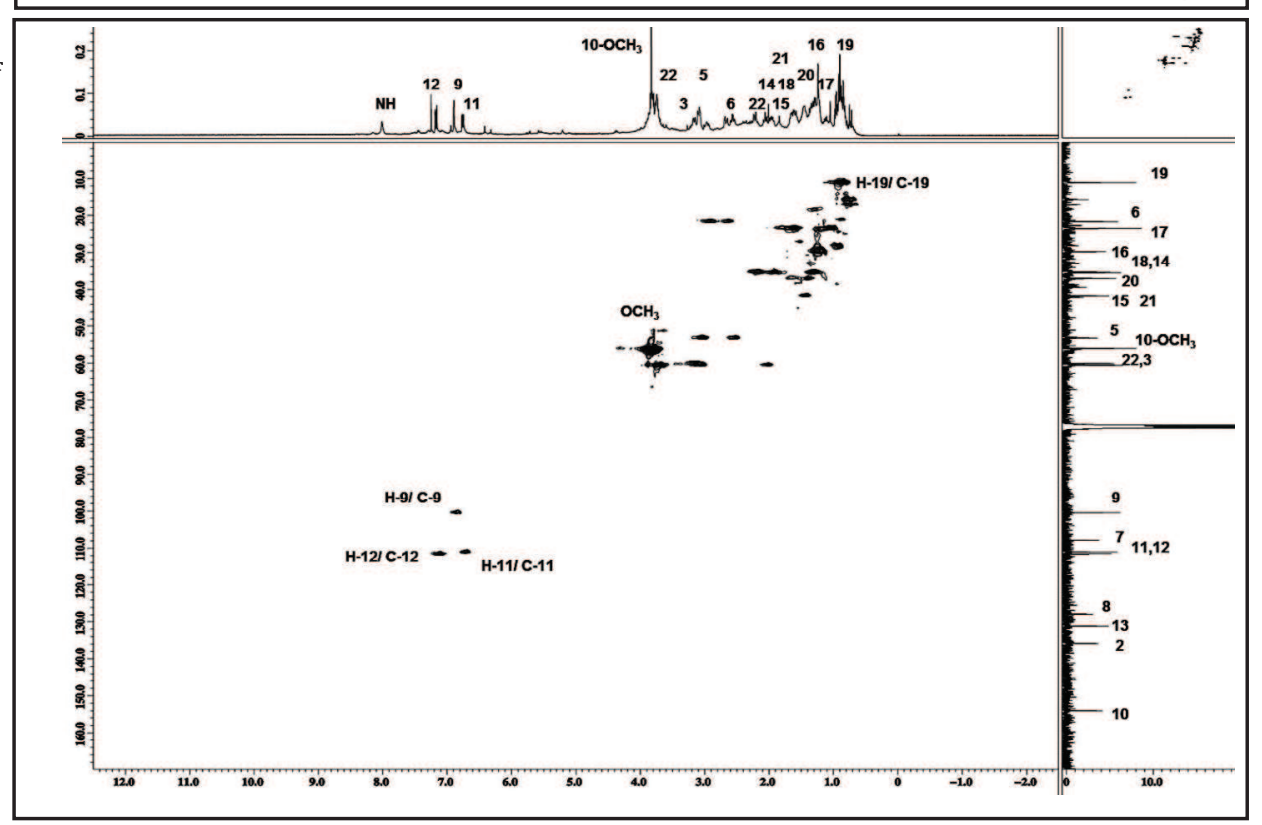




\section{Cellular Physiology Cell Physiol Biochem 2015;37:1997-2011 \begin{tabular}{l|l|l} 
DOI: 10.1159/000438560 & o 2015 S. Karger AG, Basel
\end{tabular} and Biochemistry Published online: November 20, 2015 www.karger.com/cpb \\ Fadaeinasab et al.: Cholinesterase Activity of Indole Alkaloids}

of $\delta 0.96$ was attributed to the methyl group (d, $J=6.8,3 \mathrm{H})$ attached to $\mathrm{C}-20$ (Table 1).

The ${ }^{13} \mathrm{C}$ NMR (Fig. 4) and HSQC (Fig. 5) spectra showed the presence of 21 carbon atoms: five quaternary carbons, seven methines, seven methylenes, one each methyl and methoxy group. The HMBC spectrum (Fig. 6) also showed a correlation between C-10 and the 10-OMe, confirming the position of methoxy group. The series of HMBC correlations are: H-19/C-15, $\mathrm{C}-17$; H-17/ C-15, H-14/ C-3, and the correlations between aromatic protons and their neighboring carbons in $J_{2}$ and $J_{3}$. The absolute configurations of C-3, C- $15, \mathrm{C}-20$ and C-21 of $1,(3 R, 15 R$, $20 S, 21 R$ ) were obtained by comparing the coupling constant of 1 in ${ }^{1} \mathrm{H}$ NMR with published data with the same skeleton [13]. Thus compound 1 was unambiguously assigned as rauvolfine C (1).

3-methyl-10,11-dimethoxy-6-methoxycarbonyl- $\beta$-carboline (2) was obtained as a yellowish amorphous solid. On the basis of its HRESIMS $(\mathrm{m} / \mathrm{z}$ 301.0888, $[\mathrm{M}+\mathrm{H}]^{+}$) (Fig. 7) along with the NMR data, the molecular formula was established as $\mathrm{C}_{16} \mathrm{H}_{16} \mathrm{~N}_{2} \mathrm{O}_{4}$. The IR spectrum showed a peak at $1725 \mathrm{~cm}^{-1}$, which indicate the presence of the carbonyl group and a band at $3369 \mathrm{~cm}^{-1}$, indicating the presence of the $\mathrm{NH}$ group. In the UV spectrum, the maximum absorption at 241, 282 and $332 \mathrm{~nm}$ implied the presence of a $\beta$-carboline chromophore [14]. The ${ }^{1} \mathrm{H}$ NMR spectrum (Fig. 8 ) displayed resonances attributable to a two substituted aromatic ring $(\delta 6.86$, $\mathrm{s}, 2 \mathrm{H}, \mathrm{H}-9$ and $\mathrm{H}-12)$, one methyl group $(\delta 1.29, \mathrm{~s}, 3 \mathrm{H})$, two methoxy groups $(\delta$ 3.88 , s, 3H, 10-OMe and $\delta 3.84, \mathrm{~s}, 3 \mathrm{H}, 11-$
Table 1. ${ }^{1} \mathrm{H}$ NMR $(400 \mathrm{MHz})$ and ${ }^{13} \mathrm{C}$ NMR $(100 \mathrm{MHz})$ spectral data of $\mathbf{1}$ and 2 in $\mathrm{CDCL}_{3}(\delta$ in ppm, $J$ in $\mathrm{Hz}$ )

\begin{tabular}{|c|c|c|c|c|}
\hline \multirow[b]{2}{*}{ Position } & \multicolumn{2}{|l|}{1} & \multicolumn{2}{|c|}{2} \\
\hline & ${ }^{1} \mathrm{H}-\mathrm{NMR}$ & ${ }^{13} \mathrm{C}-\mathrm{NMR}$ & ${ }^{1} \mathrm{H}-\mathrm{NMR}$ & ${ }^{13} \mathrm{C}-\mathrm{NMR}$ \\
\hline 2 & & 135.8 & & 130.2 \\
\hline 3 & $\begin{array}{c}3.20 \mathrm{dd} \\
(J=10.3,12.3)\end{array}$ & 60.0 & $1.29 \mathrm{~s}$ & 18.5 \\
\hline 4 & - & - & - & 146.4 \\
\hline 5 & $\begin{array}{l}2.90 \mathrm{~m} \\
2.45 \mathrm{~m}\end{array}$ & 53.3 & $7.52 s$ & 155.5 \\
\hline 6 & $\begin{array}{l}2.83 \mathrm{~m} \\
2.31 \mathrm{~m}\end{array}$ & 21.7 & & 120.1 \\
\hline 7 & - & 107.9 & - & 107.2 \\
\hline 8 & - & 127.0 & - & 120.1 \\
\hline 9 & $6.83 d(J=2.3)$ & 100.4 & $6.86 s$ & 100.2 \\
\hline 10 & - & 154.2 & - & 144.7 \\
\hline 11 & $\begin{array}{c}6.73 d d \\
(J=8.7,2.2)\end{array}$ & 111.0 & - & 144.7 \\
\hline 12 & $7.12 d(J=8.7)$ & 111.5 & $6.86 s$ & 95.2 \\
\hline 13 & - & 131.2 & - & 130.2 \\
\hline 14 & $\begin{array}{l}1.23 \mathrm{~m} \\
1.42 \mathrm{~m}\end{array}$ & 35.2 & - & 168.1 \\
\hline 15 & $1.54 \mathrm{~m}$ & 41.4 & & \\
\hline 16 & $\begin{array}{l}1.12 \mathrm{~m} \\
1.33 \mathrm{~m}\end{array}$ & 30.0 & & \\
\hline 17 & $\begin{array}{l}1.01 \mathrm{~m} \\
1.72 \mathrm{~m}\end{array}$ & 23.5 & & \\
\hline 18 & $\begin{array}{l}1.94 \mathrm{~m} \\
2.11 \mathrm{~m}\end{array}$ & 35.3 & & \\
\hline 19 & $0.96 d(J=6.8)$ & 11.1 & & \\
\hline 20 & $1.30 \mathrm{~m}$ & 37.1 & & \\
\hline 21 & $3.63 \mathrm{~m}$ & 55.7 & & \\
\hline 22 & $\begin{array}{l}1.93 \mathrm{~m} \\
3.55 \mathrm{~m}\end{array}$ & 60.0 & & \\
\hline $\mathrm{NH}$ & $8.10 \mathrm{brs}$ & - & 8.51 brs & - \\
\hline 10-OMe & $3.79 \mathrm{~s}$ & 55.9 & $3.88 s$ & 56.4 \\
\hline $15-0 \mathrm{Me}$ & & & $3.69 \mathrm{~s}$ & 51.2 \\
\hline $11-\mathrm{OMe}$ & & & $3.84 s$ & 56.3 \\
\hline
\end{tabular}

$\mathrm{OMe}$ ), one methoxy carbonyl (s, $\delta 3.69,3 \mathrm{H}, 15-\mathrm{OMe}$ ). In addition, a broad singlet $\mathrm{NH}$ proton signal (s, $\delta 8.51,1 \mathrm{H}, \mathrm{H}-1)$ and a singlet aromatic proton signal $(\mathrm{s}, \delta 7.52,1 \mathrm{H}, \mathrm{H}-5)$ were also observed. The ${ }^{13} \mathrm{C}$ NMR (Fig. 9) and HSQC (Fig. 10) spectra for 2 specified the presence of 16 carbon signals, consisting of three aromatic methines, eight aromatic quaternary carbon signals, three methoxy groups one methyl and a carbonyl group. The spectroscopic data proposed that 2 was a $\beta$-carboline alkaloid bearing two methoxy groups, one methoxycarbonyl group and one methyl group (Table 1). Furthermore, the HMBC (Fig. 11) correlations between 10-OMe and $\mathrm{C}-10(\delta 144.75), 11-\mathrm{OMe}$ and $\mathrm{C}-11(\delta 144.75), 15-\mathrm{OMe}$ and $\mathrm{C}=\mathrm{O}(\delta 168.10)$ confirmed the position of three methoxy groups at $\mathrm{C}-10, \mathrm{C}-11$ and $\mathrm{C}=0 \mathrm{14}$, respectively. The correlation between $\mathrm{H}-5$ and $\mathrm{C}=\mathrm{O}$ at position 14 confirmed the carbonyl group was located at position 14 . 


\section{Cellular Physiology \\ Cell Physiol Biochem 2015;37:1997-2011

Fig. 6. $\mathrm{HMBC}$ spectrum of (1).

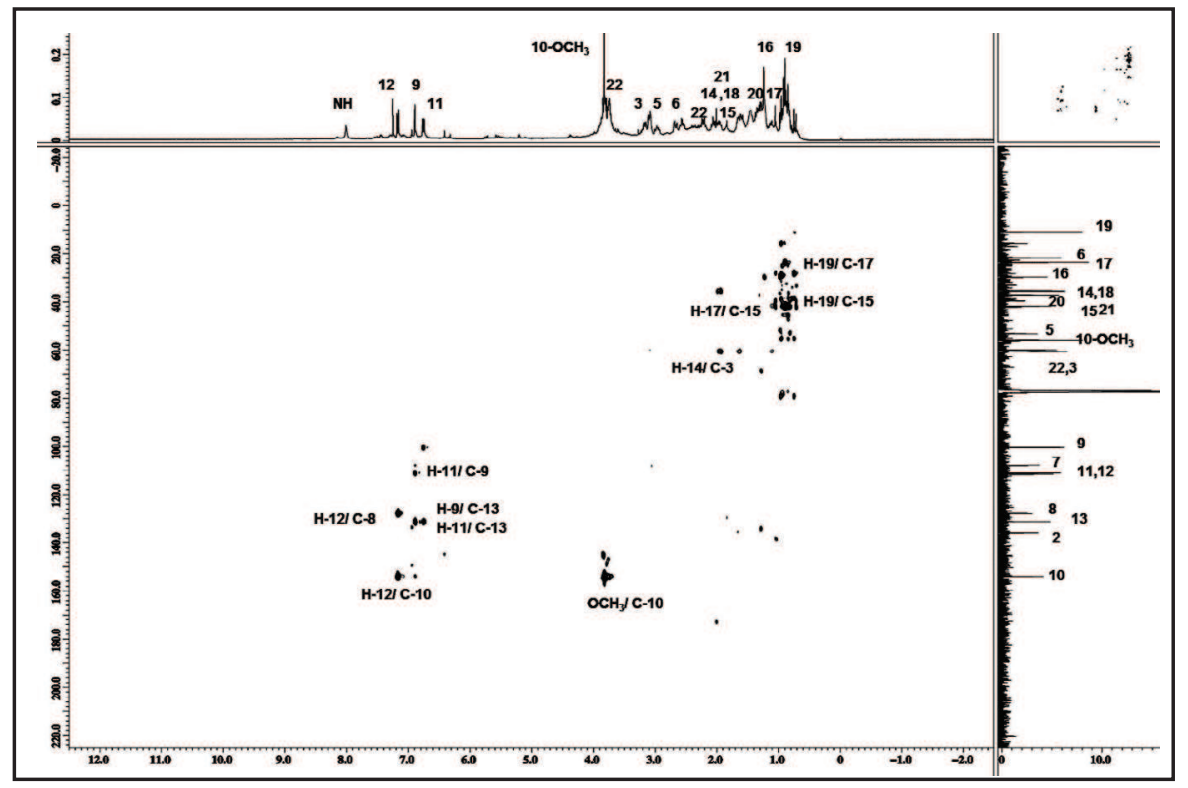

Fig. 7. Molecular weight of (2).

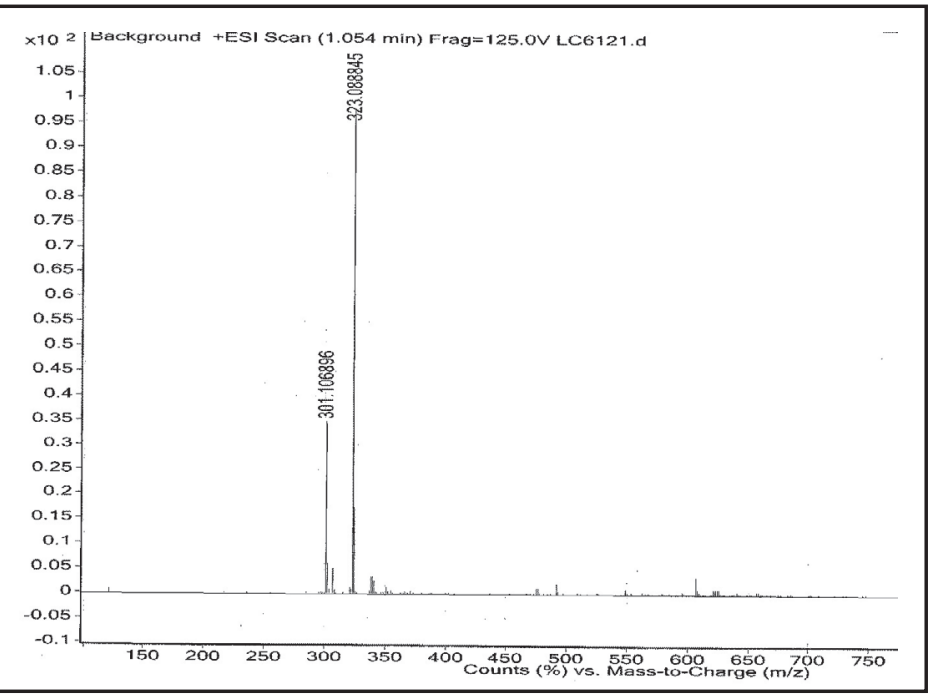

Thus the structure of 2 was determined as 3-methyl-10,11-dimethoxy-6- methoxycarbonyl$\beta$ - carboline.

Five known alkaloids, macusine B (3) [15] (Fig. 12, 13), vinorine (4) [16] (Fig. 14, 15), undulifoline (5) [17] (Fig. 16, 17), isoresrpiline (6) [13] (Fig. 18, 19), and rescinnamine (7) [18] (Fig. 20,21), were also identified on the basis of their spectroscopic profile (NMR, UV, IR and MS) and comparison to published data.

\section{Cholinesterase inhibitory activity}

AChE inhibitors are the largest group of drugs clinically approved to manage mild to moderate AD patients [19]. Alkaloids are considered the most promising candidate as cholinesterase inhibitors among the various classes of phytochemicals due to the presence of nitrogen-containing structure. The positively charged nitrogen could interact with the active site of cholinesterase, in particular at the catalytic triad [20]. Naturally occurring alkaloids such as physostigmine, galanthamine and huperzine A are potent AChE inhibitors. The indoletype alkaloid is an important class of natural AChE inhibitors [21]. Table 2 summarizes the $\mathrm{IC}_{50}$ values and selectivity indexes of the isolated indole alkaloids against $\mathrm{AChE}$ and $\mathrm{BChE}$. Briefly, all the isolated compounds displayed strong to moderate cholinesterase inhibitory activity, except for 1, which was inactive against AChE. Compound 7 showed the highest inhibitory 

Cellular Physiology Cell Physiol Biochem 2015;37:1997-2011 \begin{tabular}{l|l} 
DOI: 10.1159/000438560 & O 2015 S. Karger AG, Basel
\end{tabular} and Biochemistry Published online: November 20, 2015 www.karger.com/cpb
Fadaeinasab et al.: Cholinesterase Activity of Indole Alkaloids

Fig. 8. ${ }^{1} \mathrm{H}$ NMR spectrum of (2).

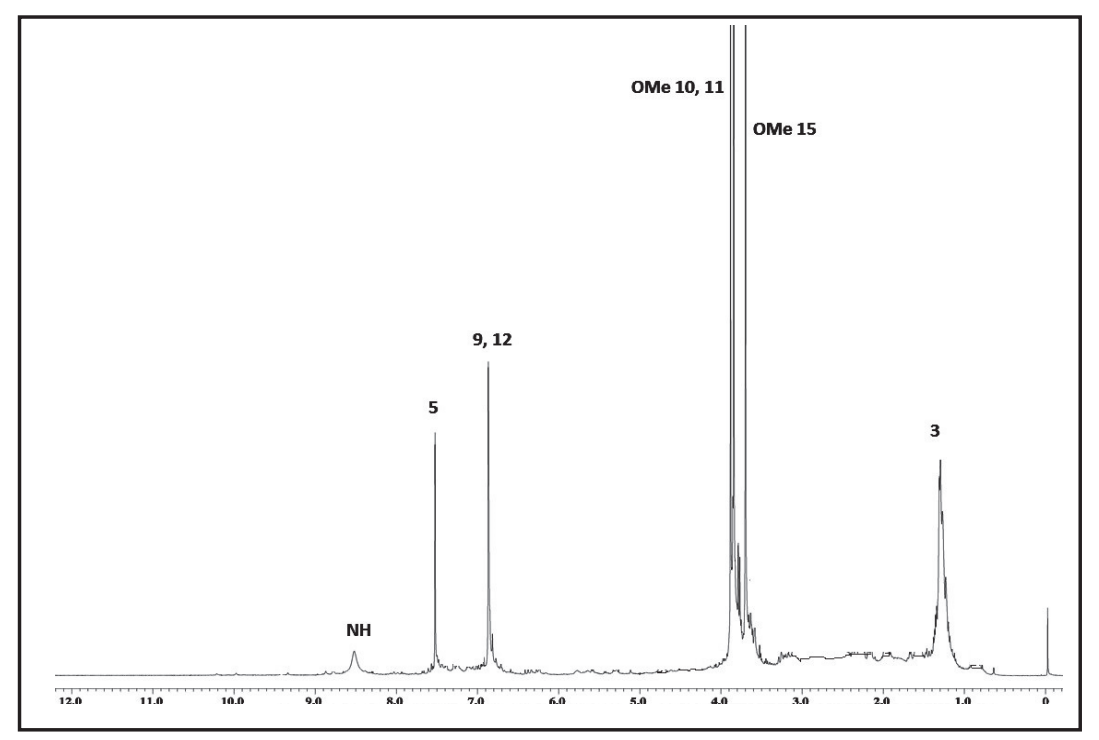

Fig. 9. ${ }^{13} \mathrm{C}$ NMR spectrum of (2).

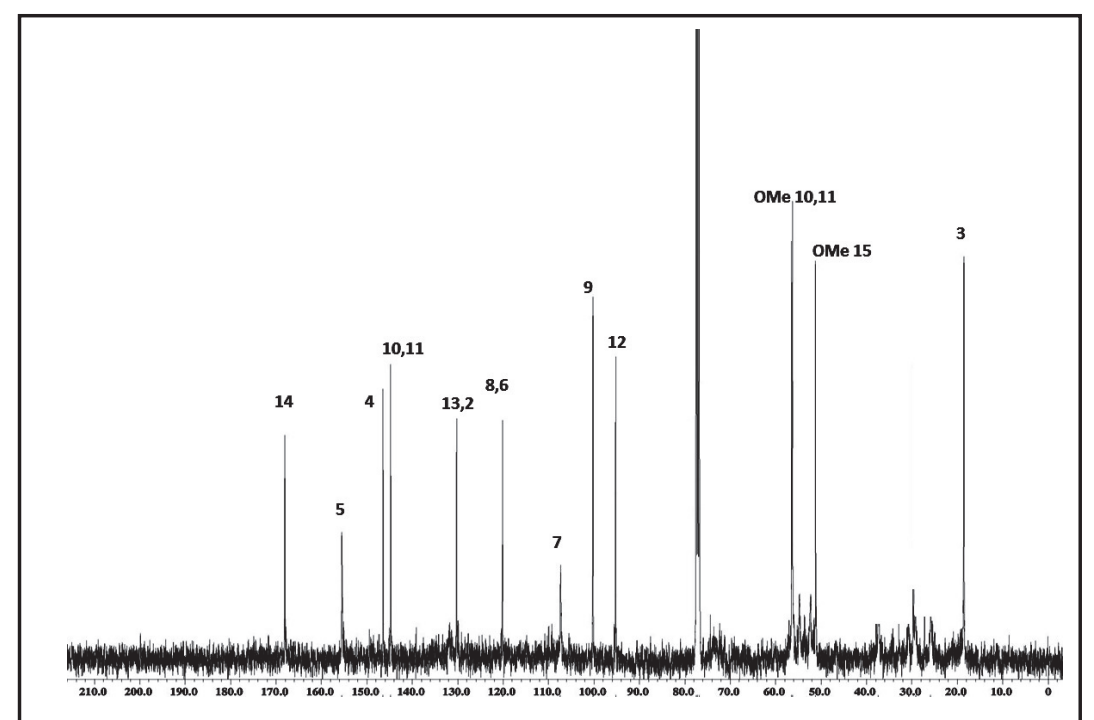

Fig. 10. HSQC spectrum spectrum of (2).

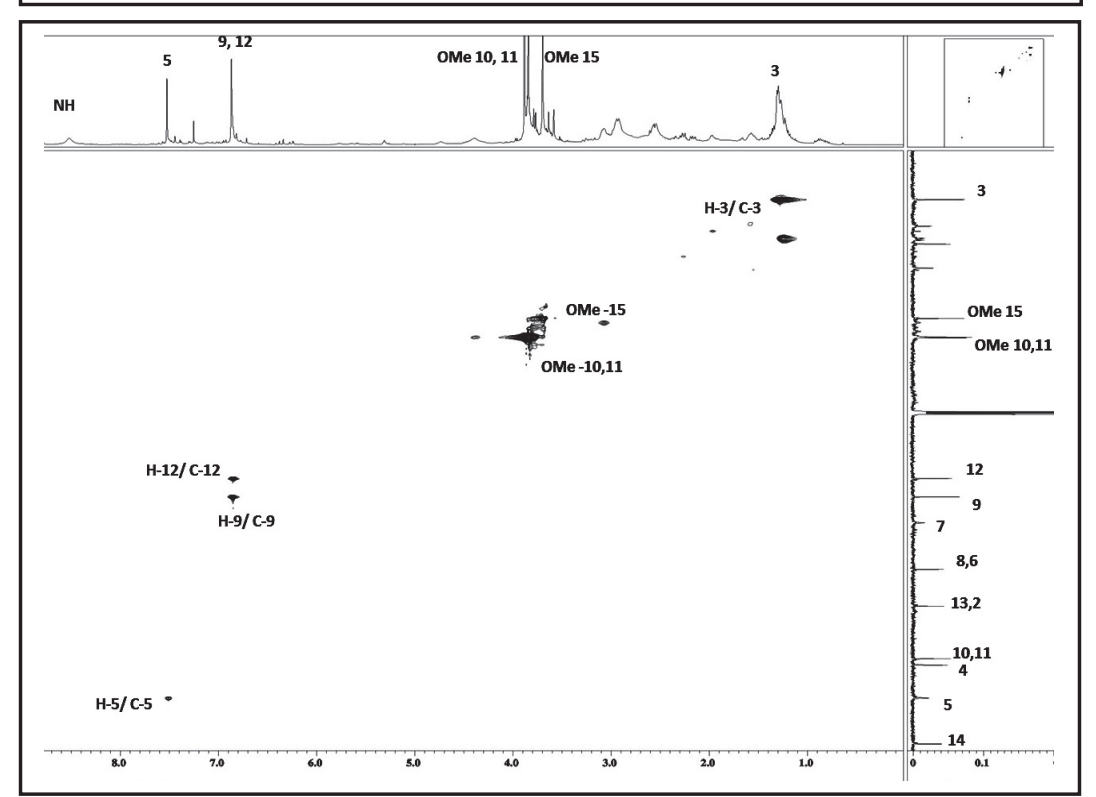




\section{Cellular Physiology \\ Cell Physiol Biochem 2015;37:1997-2011 \\ \begin{tabular}{|l|l|}
\hline DOI: $10.1159 / 000438560$ & C 2015 S. Karger AG, Basel
\end{tabular} \begin{tabular}{l|l} 
and Biochemistry Published online: November 20, 2015 & www.karger.com/cpb
\end{tabular}

Fig. 11. $\mathrm{HMBC}$ spectrum of (2).

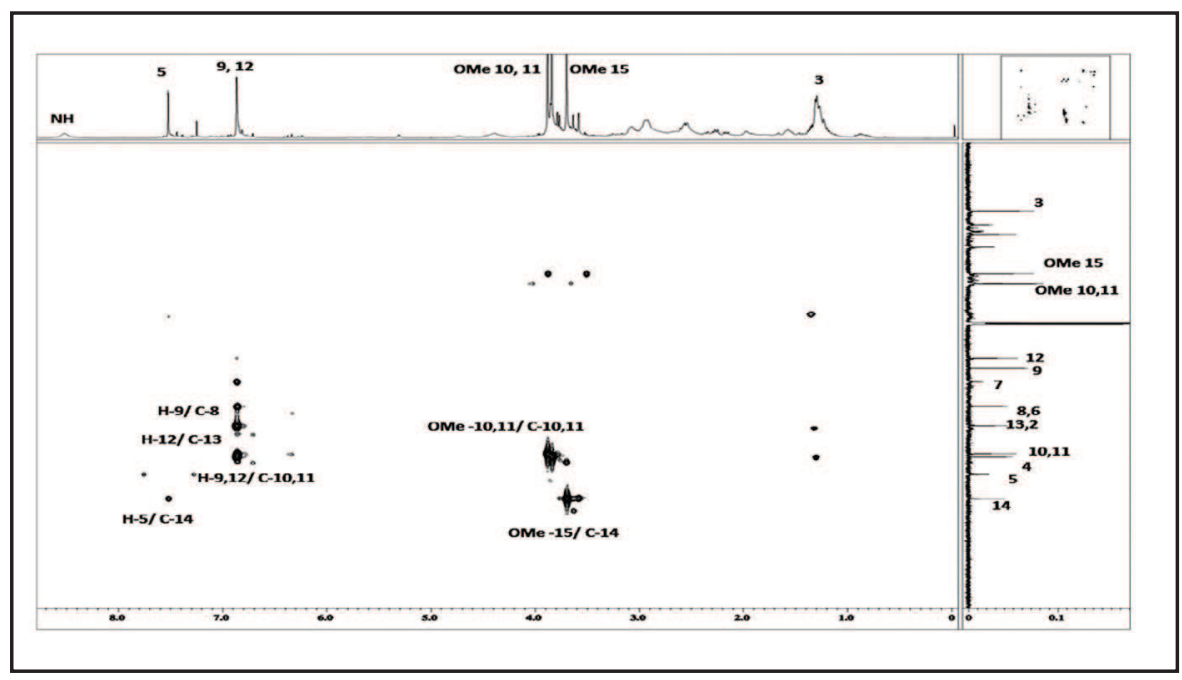

Fig. 12. ${ }^{1} \mathrm{H}$ NMR spectrum of (3).

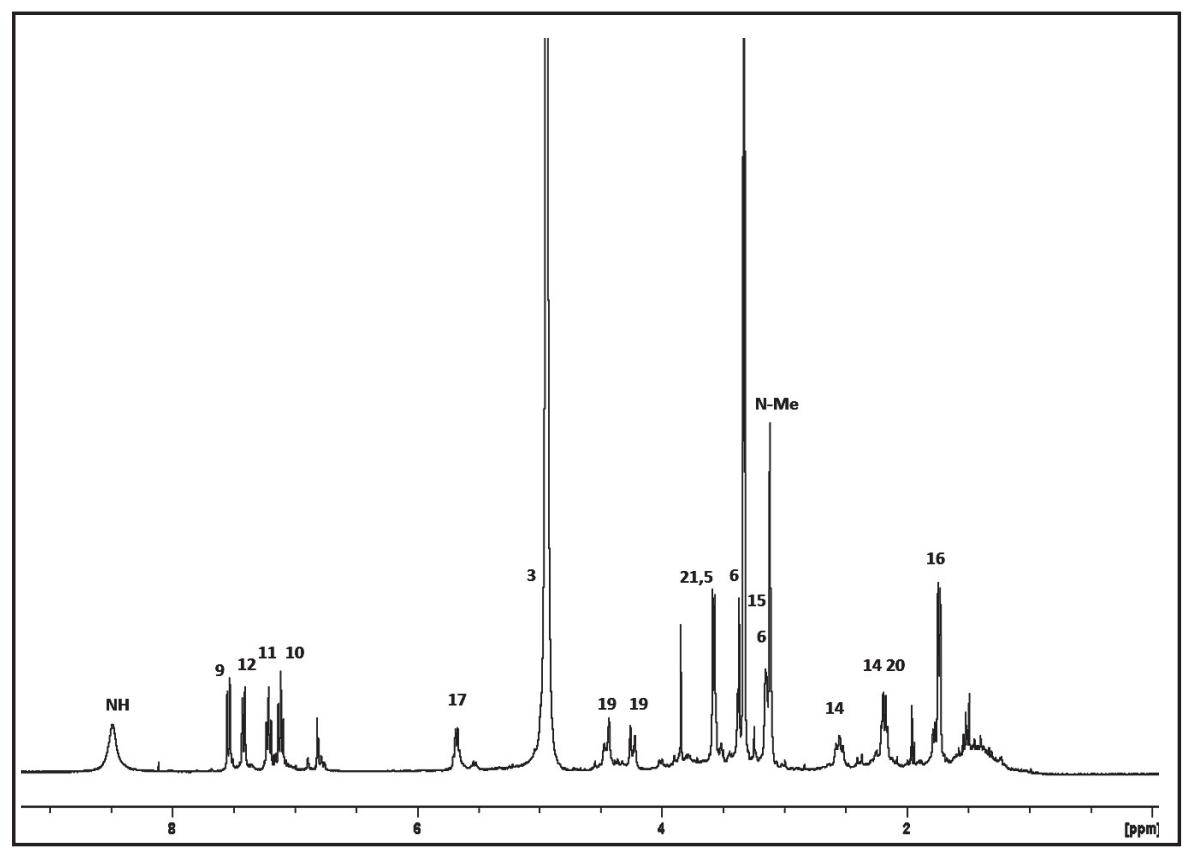

activity against both $\mathrm{AChE}$ and $\mathrm{BChE}$ with $\mathrm{IC}_{50}$ values of 11.01 and $8.06 \mu \mathrm{M}$, respectively. On the molar basis, the inhibitory activity of 7 was 5.3 times less than galanthamine on AChE. Interestingly, on $\mathrm{BChE}$, it showed 2.4 more potent than galanthamine. Likewise, compound 6 also displayed more inhibitory activity than galanthamine on BChE [22].

In the present study, compounds 1, 2, 5 and 6 were found to be selective towards $\mathrm{BChE}$, whereas compounds 3, 4 and 7 are dual inhibitors. Steroidal and triterpenoidal alkaloids were reported to be more selective BChE inhibitors, whereby some members such as buxakashmiramine, chenomorphine and chuanbeinone exhibiting potent inhibition with $\mathrm{IC}_{50}$ of lower than $1 \mu \mathrm{M}$. Similarly, some of the indole alkaloids are also more selective for BChE [20]. Liew et al. [23] reported the isolation of monoterpenoid indole alkaloids from Nauclea officinalis showing selective inhibitory activity towards BChE. Passos et al. [24] found that monoterpene indole alkaloid showed $\mathrm{BChE}$ selective inhibition with $\mathrm{IC}_{50}$ in the range of 3 to $14 \mu \mathrm{M}$ while the $\beta$-carboline alkaloids were non selective inhibitors. However, in the present study, compound 2, a $\beta$ - carboline showed BChE selective inhibition. For indole alkaloids, AChE selectivity is thought be contributed among others by the presence of alkyl groups as substituents at the indole nitrogen [24]. In the present study, absence of alkyl substituents on compounds 1, 2, 5 and 6 could explain their lack of AChE selectivity 


\section{Cellular Physiology \\ Cell Physiol Biochem 2015;37:1997-2011 DOI: 10.1159/000438560

Fig. 13. ${ }^{13} \mathrm{C}$ NMR spectrum of (3).
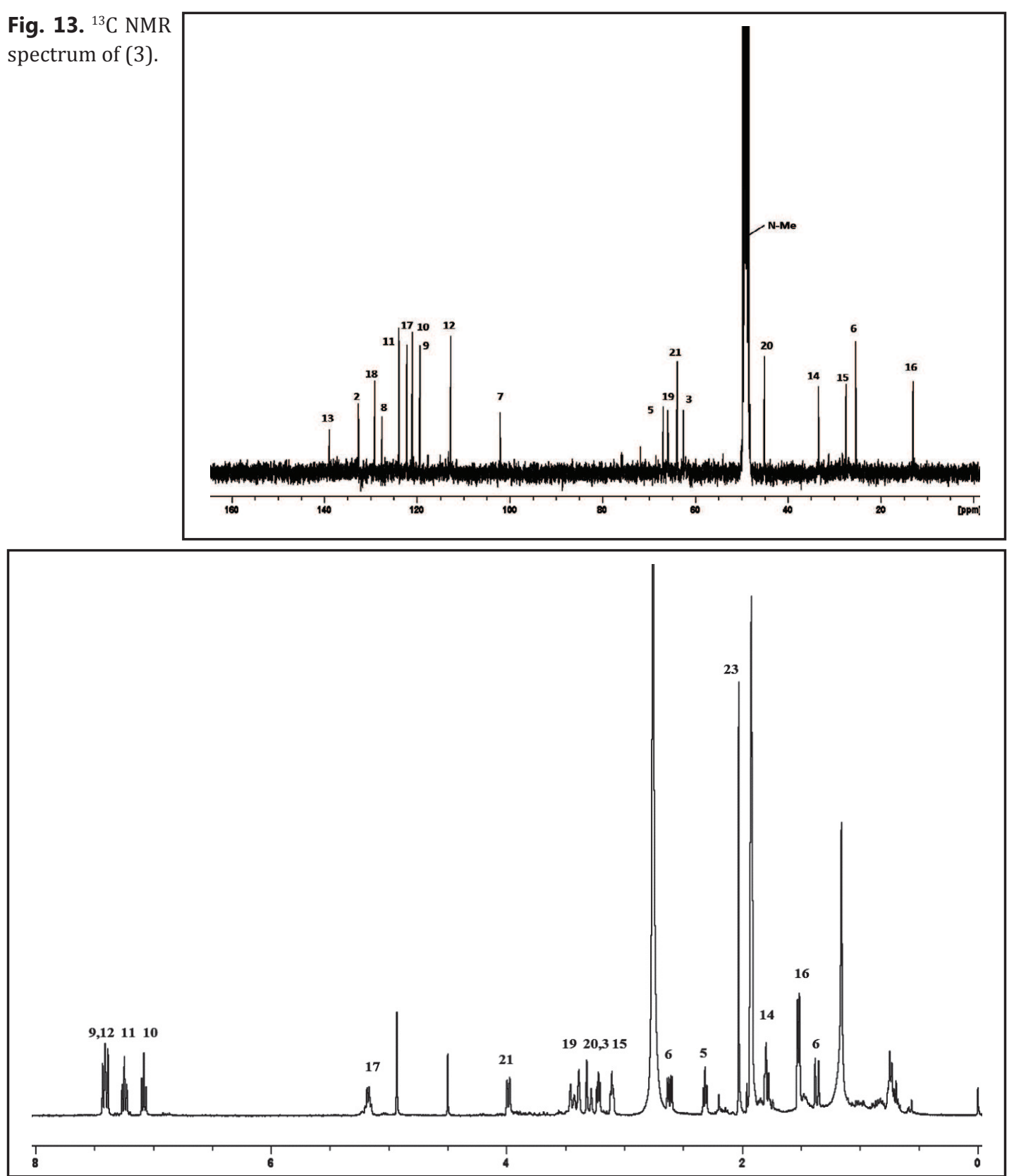

Fig. 14. ${ }^{1} \mathrm{H}$ NMR spectrum of (4).

observed. However compound 3, which has a methyl substitution, showed dual inhibitory activity rather than AChE selective inhibition. In addition, compounds 4 and 7 also showed dual inhibitory activities, having almost equal inhibitory potencies on both AChE and BChE enzymes. Although AChE plays a primary role in hydrolyzing acetylcholine, BChE was found to play an important and undiscovered role in cholinergic regulation at the affected region of the brain as AD progresses [25]. Thus, a BChE selective agent may be effective in the later stage of the neurodegeneration. On the other hand, an agent having dual inhibition on both $\mathrm{AChE}$ and $\mathrm{BChE}$, such as clinically used carbamate, rivastigmine or compound 7 may offer greater clinical efficacy along the continuum of $\mathrm{AD}[26,27]$.

Molecular docking of rescinnamine (7) and isoresrpiline (6)

The active site of cholinesterase is placed at the bottom of a long, narrow gorge comprising five important regions to accommodate and hydrolyze the acetylcholine [28]. 


\section{Cellular Physiology \\ Cell Physiol Biochem 2015;37:1997-2011

Fig. 15. ${ }^{13} \mathrm{C}$ NMR spectrum of (4).

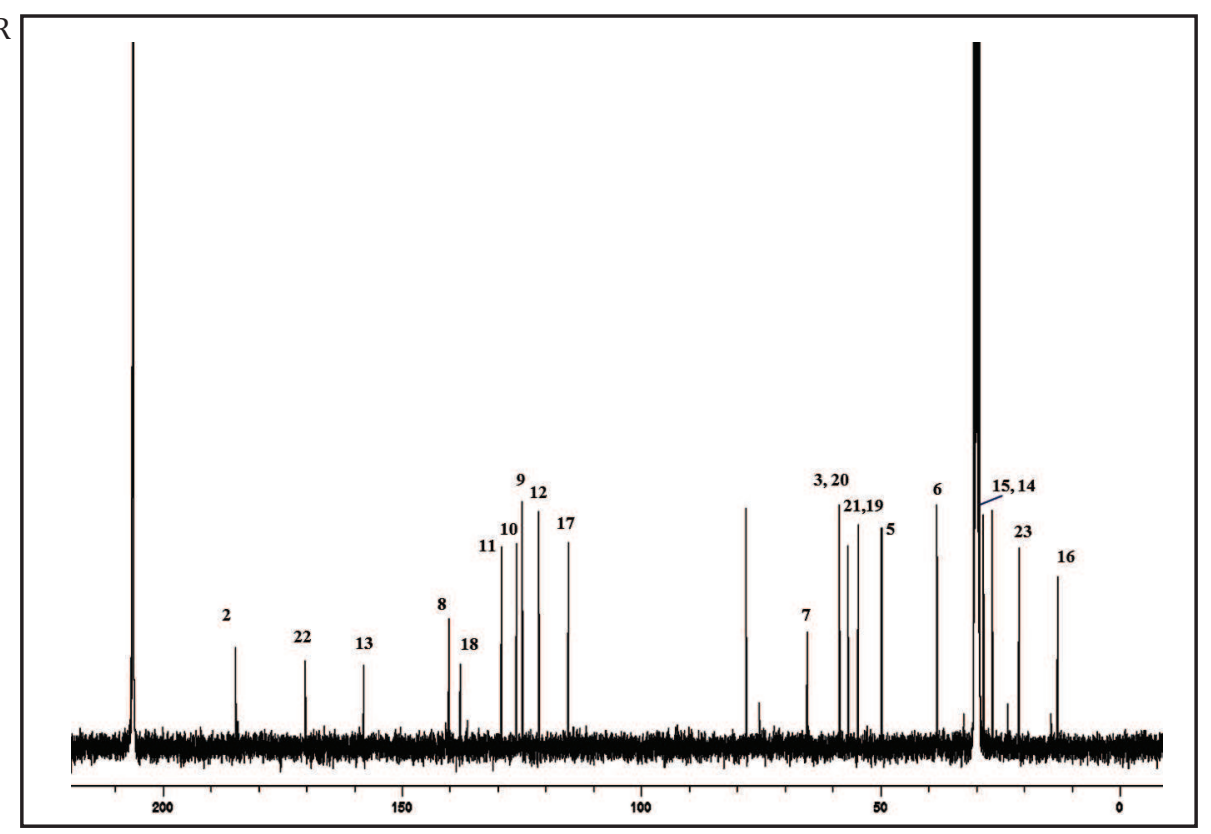

Fig. 16. ${ }^{1} \mathrm{H} N M R$ spectrum of (5).

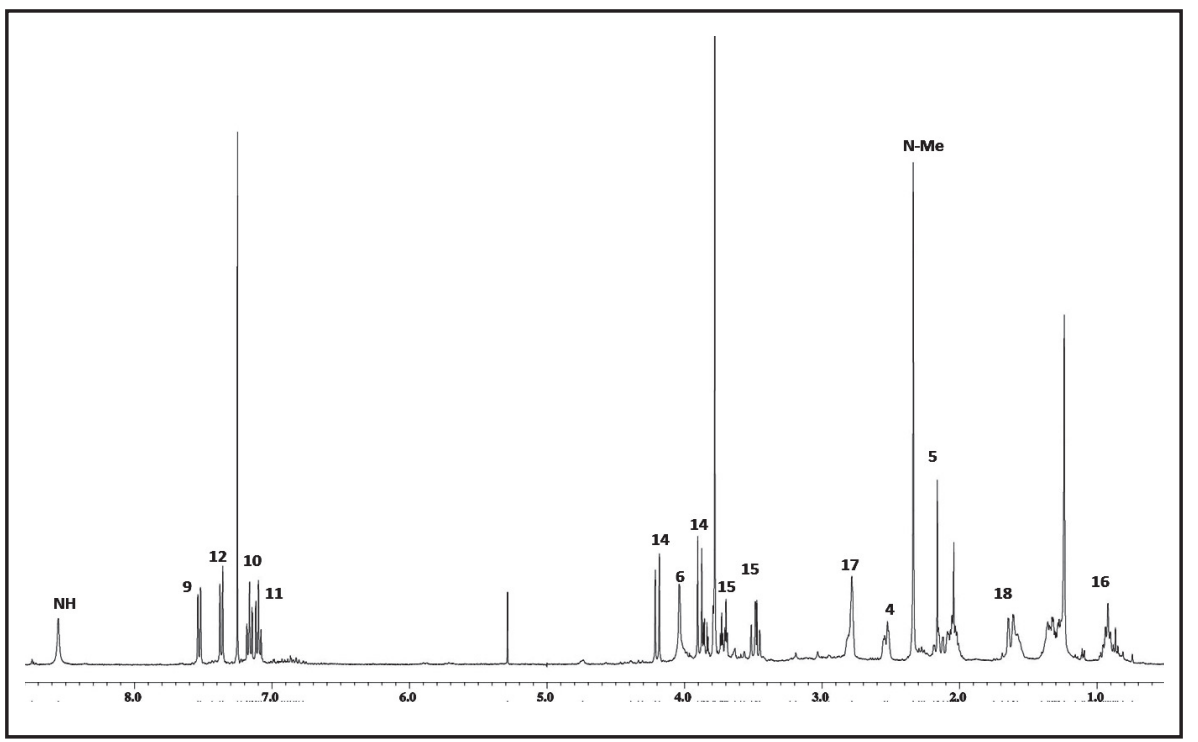

However, the gorge of AChE is only capable of accommodate smaller molecules due to insufficient gorge space in contrary to BChE, which is able to accept bulkier substrates and molecules. Nevertheless, in our case, compounds 7 and 6, despite their bulkiness, were found to be the strong inhibitor of both $\mathrm{AChE}$ and $\mathrm{BChE}$.

To understand the electronic interactions between the compounds and the residues composing the active site of cholinesterases, they were docked into the active site of AChE from crystal structure of Torpedo californica and BChE from human BChE. Fig. 22a shows the conformations and binding interactions of 7 at the active site of AChE. The findings revealed that compound 7 was accommodated into active site gorge of AChE enzyme by the aid of strong hydrophobic interactions between the indole moiety with Trp 279 at the entrance of the gorge (peripheral anionic site) and between the aromatic ring at the side chain with Trp 84 at the choline binding site. In addition, it also showed hyrdophobic interactions to Tyr 334 and Tyr 121 at peripheral anionic site, Phe 288 and Phe 290 at acyl binding pocket and mild polar interactions to Gly 117 and Gly 118 at oxyanion hole of the enzyme. It can be deduced that specific planner positioning of 7 and its strong binding interactions to active site amino acid residues are responsible for the inhibitory potency of this compound. On 


\section{Cellular Physiology \\ Cell Physiol Biochem 2015;37:1997-2011

Fig. 17. ${ }^{13} \mathrm{C}$ NMR spectrum of (5).

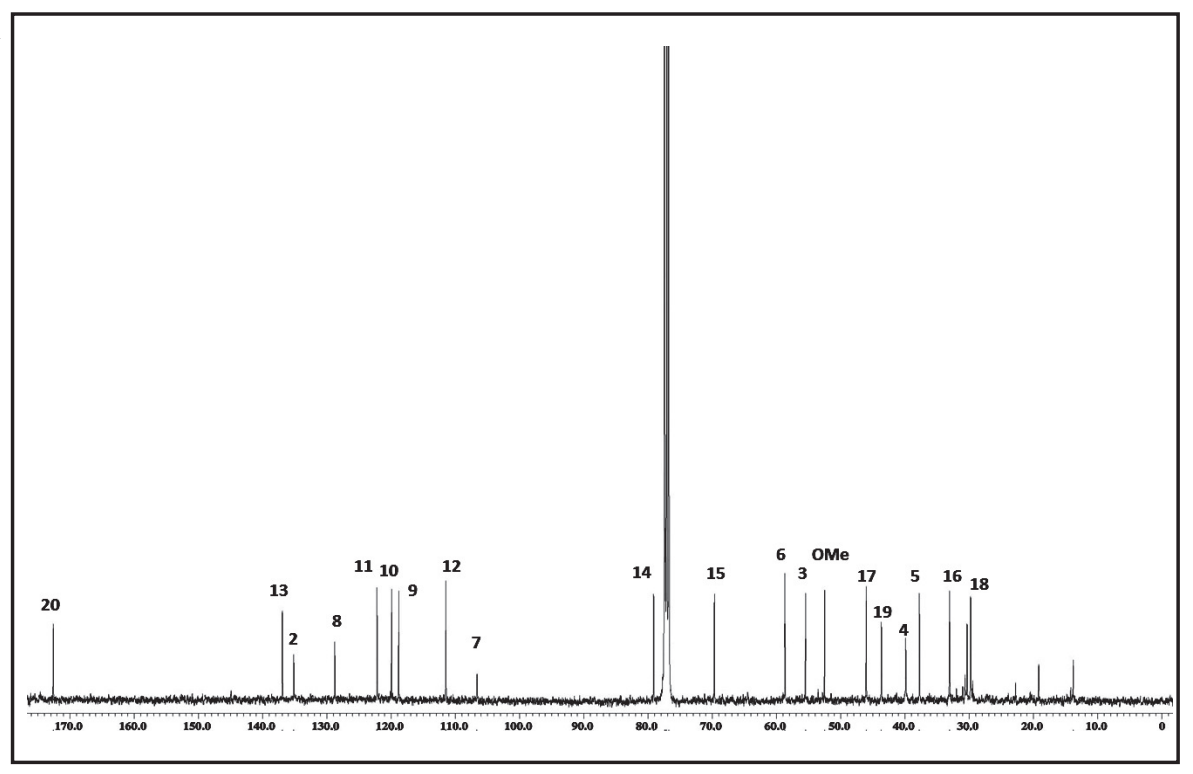

Fig. 18. ${ }^{1} \mathrm{H}$ NMR spectrum of (6).

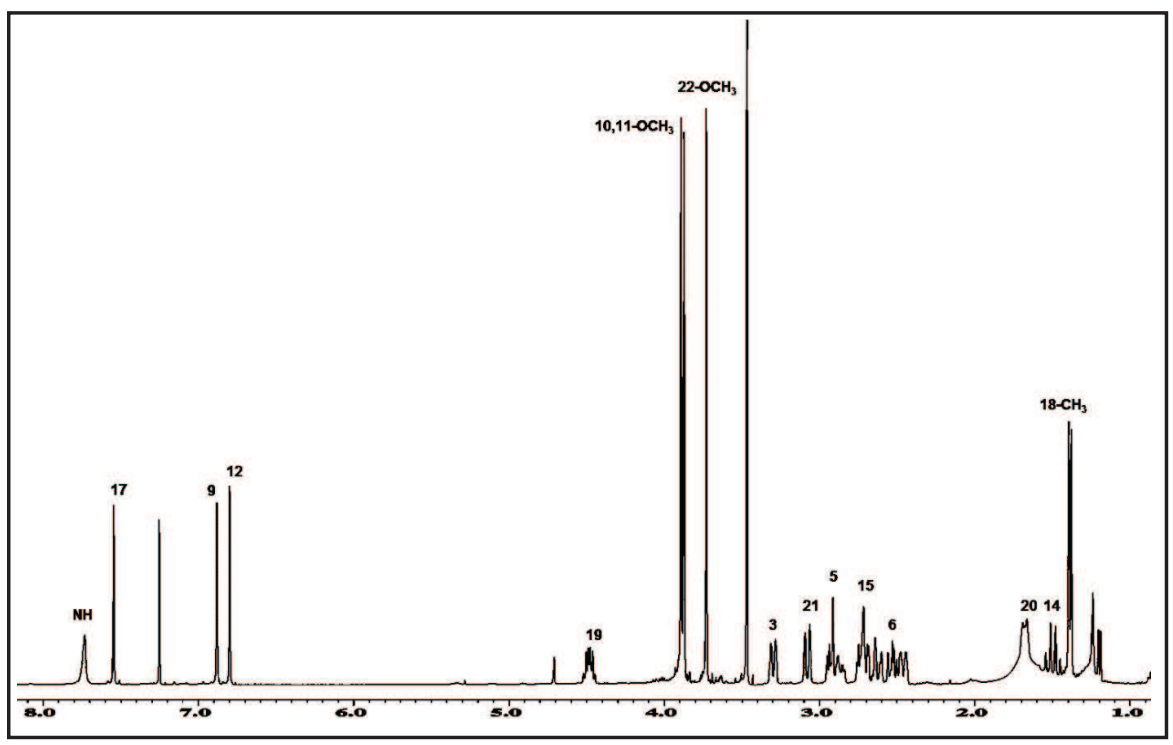

the other hand, compound 6 displayed two strong hydrogen bonds between the methoxy substituents at the indole moiety with the residues at the peripheral anionic site of AChE, namely; Phe 288 (2.59 ̊) and Arg 289 (2.53 ̊̊) as shown in Fig. 23a. Furthermore, 6 showed hydrophobic interactions with peripheral anionic site residues, including: Trp 279, Tyr 121, Tyr 70 as well as mild polar interactions with residue composing oxyanion hole of the enzyme such as Gly 117 and Gly 188. The docking analysis suggests that compound 6 had slight structural bending and partially blocked the AChE active site.

Several researchers have investigated the molecular interactions of indole alkaloids at the active site of cholinesterase enzymes. The indole moiety of coronaridine, an indole alkaloid isolated from Ervatamia hainanensis with strong AChE inhibitory activity IC $_{50}$ of $8.6 \mu \mathrm{M}$ ) showed a $\pi-\pi$ interaction with Trp 84 (choline binding site) while the nitrogen atom at azepane ring has a stable p- $\pi$ interaction with Trp 279 [29]. Likewise, for the quartenary $\beta$-carboline alkaloids isolated from Psychotria laciniata, namely prunifoleine and 14-oxoprunifoleine, a stacking interaction was observed between aromatic ring of indole moiety of and Trp 84 at choline bonding site of AChE [24]. Additionally, these alkaloids had hydrogen bond between endocyclic oxygen with Tyr 121 at the peripheral anionic site (PAS) and van der Waals force interaction with Phe 290, Phe 330 and Phe 331 (acyl binding 
Fig. 19. ${ }^{13} \mathrm{C}$ NMR spectrum of (6).

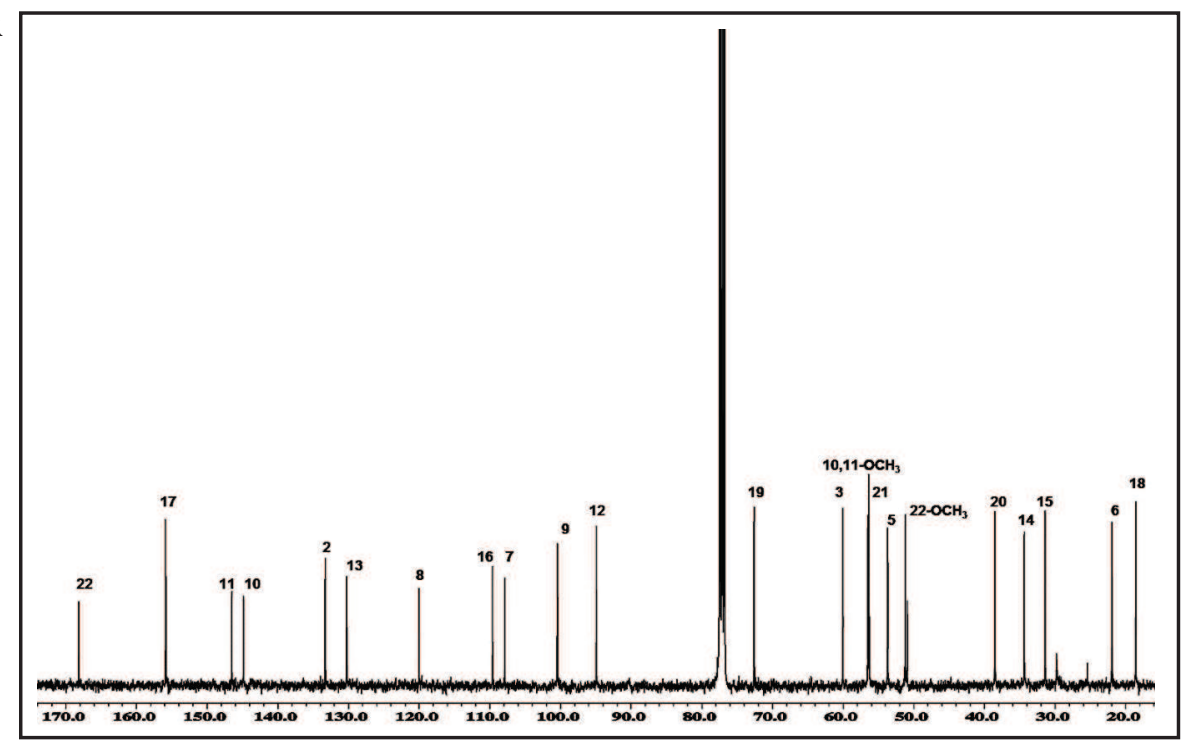

Fig. 20. ${ }^{1} \mathrm{H}$ NMR spectrum of (7).

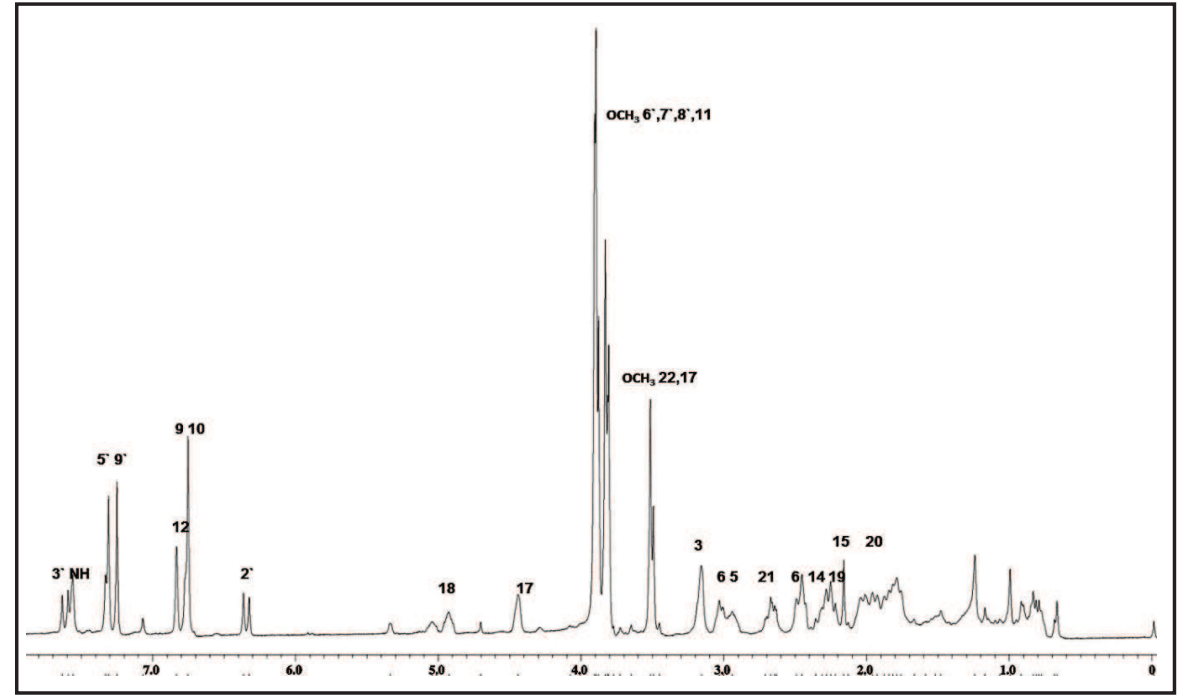

Fig. 21. ${ }^{13} \mathrm{C}$ NMR spectrum of (7).

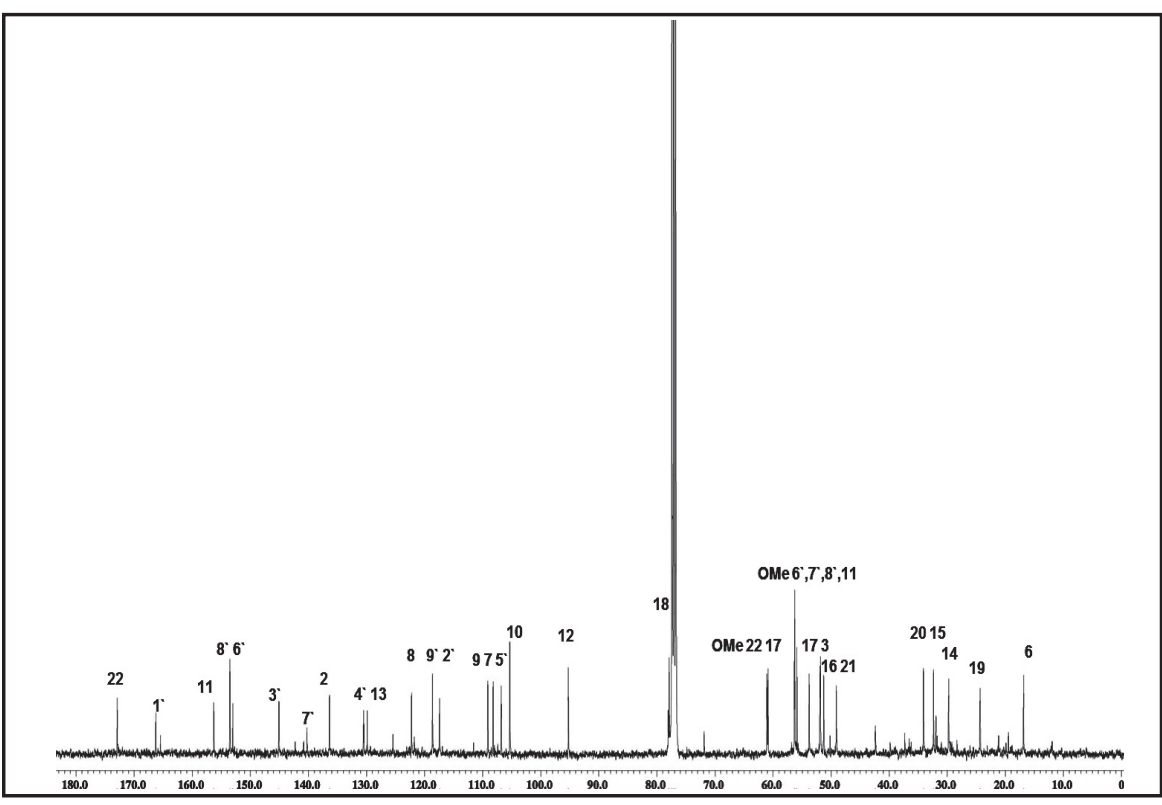




\section{Cellular Physiology Cell Physiol Biochem 2015;37:1997-2011 \begin{tabular}{l|l|l} 
DOI: 10.1159/000438560 & o 2015 S. Karger AG, Basel
\end{tabular} and Biochemistry Published online: November 20, 2015 www.karger.com/cpb \\ Fadaeinasab et al.: Cholinesterase Activity of Indole Alkaloids}

Table 2. Cholinesterase inhibitory activity of indole alkaloids of $R$. reflexa. Data presented as Mean $\pm \mathrm{SD}(\mathrm{n}=3)$. a Selectivity for $\mathrm{AChE}$ is defined as $\mathrm{IC}_{50}(\mathrm{BChE}) / \mathrm{IC}_{50}(\mathrm{AChE})$. ${ }^{\text {b Selectivity for }}$ $\mathrm{BChE}$ is defined as $\mathrm{IC}_{50}(\mathrm{AChE}) / \mathrm{IC}_{50}(\mathrm{BChE})$. ND - not determined

\begin{tabular}{ccccccc}
\hline Sample & \multicolumn{2}{c}{ AChE inhibition, $\mathrm{IC}_{50}$} & \multicolumn{2}{c}{$\mathrm{BChE}$ inhibition, IC 50} & \multicolumn{2}{c}{ Selectivity for } \\
& $\mu \mathrm{g} / \mathrm{mL}$ & $\mu \mathrm{M}$ & $\mu \mathrm{g} / \mathrm{mL}$ & $\mu \mathrm{M}$ & $\mathrm{AChE}^{\mathrm{a}}$ & $\mathrm{BChE}^{\mathrm{b}}$ \\
\hline Methanol extract & $11.04 \pm 0.14$ & - & $6.27 \pm 0.18$ & - & - & - \\
1 & $\mathrm{ND}$ & $\mathrm{ND}$ & $23.74 \pm 0.23$ & 73.23 & - & - \\
2 & $19.63 \pm 0.27$ & 65.44 & $6.45 \pm 0.11$ & 21.52 & 0.33 & 3.04 \\
3 & $14.91 \pm 0.21$ & 48.39 & $12.52 \pm 0.15$ & 40.63 & 0.84 & 1.19 \\
4 & $11.71 \pm 0.16$ & 35.06 & $12.16 \pm 0.16$ & 36.40 & 1.04 & 0.96 \\
5 & $18.62 \pm 0.22$ & 54.76 & $9.69 \pm 0.23$ & 28.51 & 0.52 & 1.92 \\
6 & $10.26 \pm 0.13$ & 24.89 & $4.92 \pm 0.09$ & 11.96 & 0.48 & 2.08 \\
7 & $6.98 \pm 0.11$ & 11.01 & $5.11 \pm 0.16$ & 8.06 & 0.73 & 1.37 \\
Galanthamine & $0.60 \pm 0.01$ & 2.09 & $5.55 \pm 0.01$ & 19.34 & 9.25 & 0.11 \\
\hline
\end{tabular}

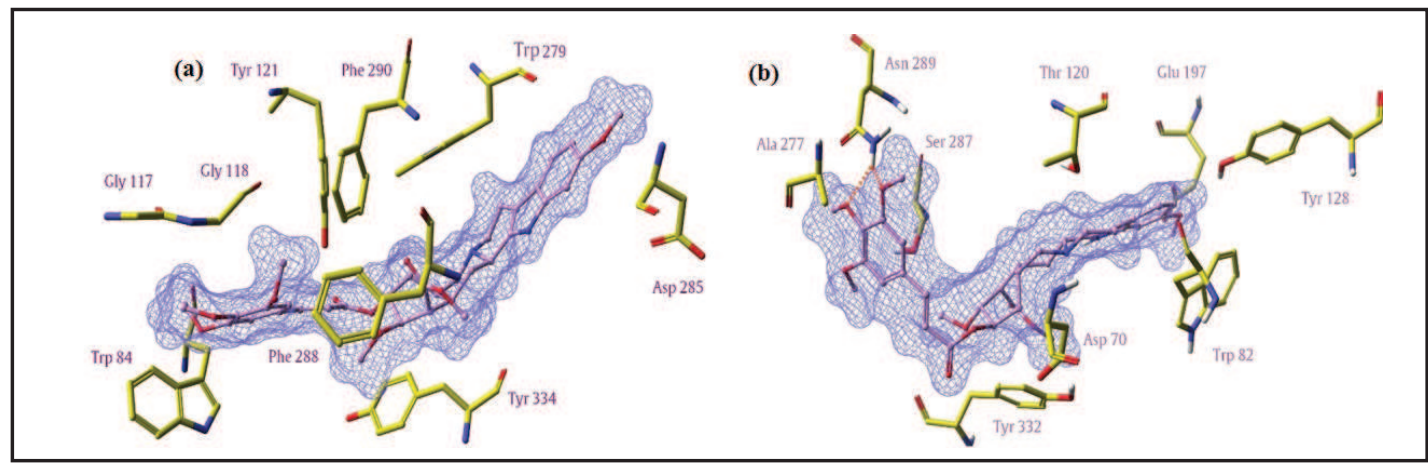

Fig. 22. Binding orientations and interactions of 7 with protein residues at the active site of (a) acetylcholinesterase and (b) butyrylcholinesterase.

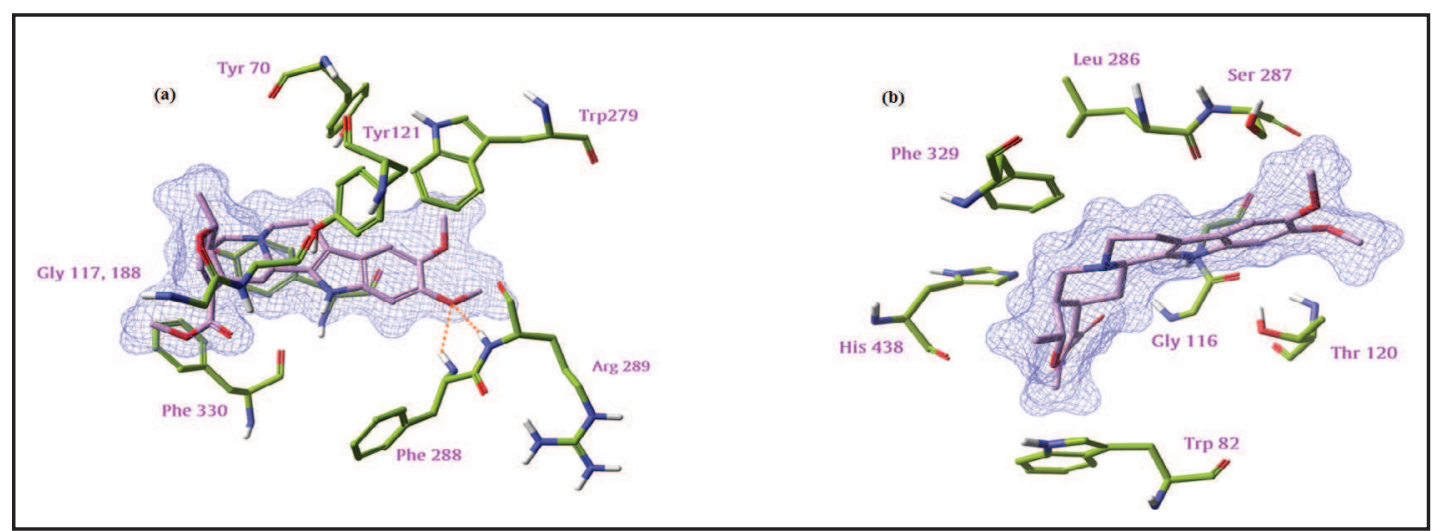

Fig. 23. Binding orientations and interactions of 6 with protein residues at the active site of (a) acetylcholinesterase and (b) butyrylcholinesterase.

pocket). In contrast to these studies which suggest that indole moiety interacted mainly with the choline binding site, the indole moiety of the compounds 6 and 7 interacted mainly with the ligands lining the entrance or peripheral anionic site of AChE.

Compound 7 showed different orientation at the active site of BChE (Fig. 22b). It was strongly attached at the enzyme active site by two relatively strong $\mathrm{H}$-bonding interactions to Asn 289 ( 1.42 and $2.00 \AA$ ) at entrance of the gorge and a $\pi, \pi$-stacking interaction to Trp 82 at choline binding site at the bottom of the gorge, completely blocking active site of the enzyme 


\section{Cellular Physiology Cell Physiol Biochem 2015;37:1997-2011

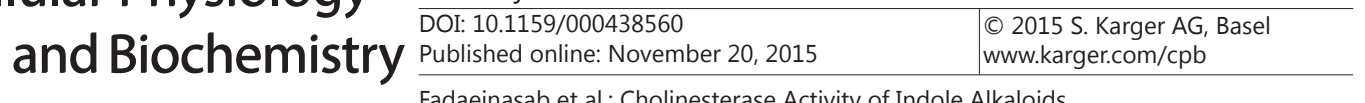

and prohibiting insertion and hydrolysis of substrate. Compound 7 also had a hydrophobic interaction with Ala 277 and mild polar interaction with Ser 287 at peripheral anionic site, as well as with Thr 120, Asp 70, Tyr 332 and Glu 197. On the other hand, compound 6 was completely accommodated at the active site of BChE, having nonpolar and hydrophobic interactions with the residue composing acyl binding pocket and catalytic triad of enzyme such as Leu 286 and His 438 (Fig. 23b). This compound also showed a strong $\pi-\pi$ stacking interaction with Trp 82 at the choline binding site and bottom of the gorge that could be responsible for its potent $\mathrm{BChE}$ inhibitory activity.

Indole alkaloids of Psychotria laciniata (e.g. angustine, vallesiachotamine lactone, vallesiachotamine) showed selective BChE inhibitory activity [24]. Docking simulation revealed that vallesiachotamine and its lactone bind to the $\mathrm{BChE}$ active site by formation of a hydrogen bond between the indole ring and the catalytic triad residues (Ser 198 and His 438). Likewise, 14-oxoprunifoleine, a $\beta$ - carboline alkaloid showed polar contacts between the nitrogen of the indole group and Ser 198 and His 438. However, angustine, the most active BChE inhibitor, binds in a different manner, mainly by hydrophobic interactions between the aromatic moieties of the molecule with the peripheral anionic and choline binding sites, as well as acyl binding pocket [24]. In comparison, the docking results of the present study suggest that methoxy groups of compounds 6 (at aromatic ring of side chain) and 7 (at indole ring) are primarily responsible for the strong inhibition via interactions with the residues at the active site of BChE.

\section{Conclusions}

The phytochemical investigation of Rauvolfia reflexa bark yielded two new indole alkaloids, rauvolfine $C$ (1) and 3-methyl-10,11-dimethoxy-6-methoxycarbonyl- $\beta$-carboline (2), and five known alkaloids macusine B (3), vinorine (4), undulifoline (5), isoresrpiline (6), and rescinnamine (7). On their cholinesterase inhibitory potential, compound 7 was found to be the most potent inhibitor of both AChE and BChE. Compounds 1, 2, 5 and 6 were found to be selective towards BChE, while compounds 3, 4 and 7 were dual inhibitors, having almost equal inhibitory effect on both AChE and BChE. Molecular docking revealed that compounds 6 and 7 interacted differently on $\mathrm{AChE}$ and $\mathrm{BChE}$, by means of hydrophobic interactions and hydrogen bonding. In $\mathrm{AChE}$, the indole moiety of both compounds interacted with the residues lining the peripheral anionic site, whereas in $\mathrm{BChE}$, their methoxy groups are primarily responsible for their strong inhibitory activity via interactions with residues at the active site of the enzyme.

\section{Acknowledgments}

The authors would like to express their utmost gratitude and appreciation to University of Malaya and Ministry of Education UM-MOHE UM.C/625/1/HIR/MOHE/SC/09 for financial support.

\section{Disclosure Statement}

No conflict of interest.

\section{References}

1 Arvind Kumar MK, Upadhyay, AK, Anupa T, Bikram DO: Quantitative determination of yohimbine alkaloid in the different part of the Rauvolfia tetraphylla. J Chem Pharm Res 2011;3:907-910.

2 Mia MM, Kadir MF, Hossan MS, Rahmatullah M: Medicinal plants of the Garo tribe inhabiting the Madhupur forest region of Bangladesh. Am Eurasian J Sustain Agric 2009;3:165-171.

3 Schultes RE: Plants in treating senile dementia in the Northwest Amazon. J Ethnopharmacol 1993;38:121128.

\section{KARGER}




\section{Cellular Physiology Cell Physiol Biochem 2015;37:1997-2011

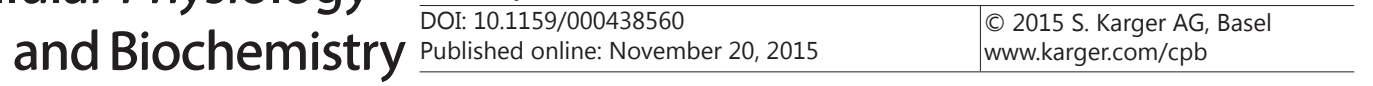 \\ Fadaeinasab et al.: Cholinesterase Activity of Indole Alkaloids}

4 Palomero GN, Bidmon HJ, Cremer M, Schleicher A, Kircheis G: Neurotransmiter receptor imbalances in motor cortex and basal ganglia in hepatic encephalopathy. Cell Physiol Biochem 2009;24:291-306.

5 Ballard CG: Advances in the treatment of Alzheimer's disease: benefits of dual cholinesterase inhibition. Eur Neurol 2002;47:64-70.

6 Pany Y, Chen Y, Yu X, Wang T, Zhang L, He Y, Zheng Y, Zheng J: The synthesis of a novel chalcone and evaluation for anti- free radical activity and antagonizing the learning impairments in Alzheimer's model. Cell Physiol Biochem 2012;29:949-958.

7 Dall'Acqua S: Plant-derived acetylcholinesterase inhibitory alkaloids for the treatment of Alzheimer's disease. Bot Targets Ther 2013;3:19-28.

8 Marcus OW, Benjamin Hundsdorfer SG, Janine M, Velerie CZ, Christoph PS, Viola JH: PS dependent APP cleavage regulates glucosylceramide synthase and is affected in Alzheimer's disease. Cell Physiol Biochem 2014;34:92-110.

9 Kato L, Marques BR, Koch I, Sumiko KL: Indole alkaloids from Rauvolfia bahiensis (Apocynaceae). Phytochemistry 2002;60:315-320.

10 Liu Z, Yang D, Xie P, Ren G, Sun G, Zeng X: MiR-106 b and MiR- 15b modulate apoptosis and angiogenesis in mycardial infraction. Cell Physiol Biochem 2012;29:851-862.

11 Fadaeinasab M, Hamid H, Kia Y, Basiri A, Murugaiyah V: Cholinesterase enzymes inhibitors from the leaves of Rauvolfia reflexa and their molecular docking study. Molecules 2013;18:3779-3788.

12 Verpoorte RJ: Annual review of plant physiology and plant molecular biology. Nat Prod Rep 1986;49:1-25.

13 Cancelieri NM, Curcino Vieira IJ, Schripsema J, Mathias L, Braz-Filho R: Darcyribeirine, a novel pentacyclic indole alkaloid from Rauvolfia grandiflora Mart. Tetrahedron Lett 2002;43:1783-1787.

14 Wei-Hua J, Hao G, Chen- Yang L, Guang- Xiong Z, Susumu, K, Atsuko, O, Xin-Sheng Y: $\beta$ - carboline alkaloids from the stems of Picrasma quassioides. Magn Reson Chem 2010;48:490-495.

15 Quetin LJ, Ancenot L, Dupont L, Bisset NG: Isolation and purification of panarine, A. Alkaloid from a Venezuelan curare. Phytochemistry 1998;27:4002-4004.

16 Falkenhagen H, Kuzovkina IN, Alterman IE, Nikolaeva LA, Stöckigt J: Alkaloid formation in hairy roots and cell suspensions of Rauwolfia serpentina Benth. Nat Prod Lett 1993;3:107-112.

17 Massiot G, Nuzillard JM, Nuzillard JM, le men-Olivier L: Alkaloids from Alstonia undulifolia. Phytochemistry 1992;31:1078-1079.

18 Azeem S, Wasif K, Ataullah M: Characterization of oxidation products of Rauvolfia alkaloids. Pak J Pharm Sci 2005;18:33-35.

19 Busch S, Wu L, Feng Y, Gretz N, Hoffmann S, Hammes HP: Alzheimer's disease and rentinal neurodegeneration share a consistent stress response of the neuro vascular unit. Cell Physiol Biochem 2012;30:1436-1443.

20 Konrath EL, Passos CS, Klein-Junior LC, Henriques AT: Alkaloids as a source of potential anticholinesterase inhibitors for the treatment of Alzheimer's disease. J Pharm Pharmacol 2013;65:1701-1725.

21 Houghton PJ, Ren YH, Howes MJ: Acetylcholinesterase inhibitors from plants and fungi. Nat Prod Rep 2006;23:181-199.

22 Lilienfeld S: Galantamine a novel cholinergic drug with a unique dual mode of action for the treatment of patients with Alzheimer's disease. CNS Drug Reviews 2002;8:159-176.

23 Liew SL, Khaw KY, Murugaiyah V, Looi CY, Wong YL, Mustafa MR, Litaudon M, Awang K: Natural indole butyrylcholinesterase inhibitors from Nauclea officinalis. Phytomedicine 2015;22:45-48.

24 Passos CS, Simões-Pires CA, Nurisso A., Soldi TC, Kato L, de Oliveira LCMA, de Faria EO, Marcourt L, Gottfried C, Carrupt PA, Henriques AT: Indole alakaloids of Psychotria as multifunctional cholinesterases and monoamine oxidases inhibitors. Phytochemistry 2013;86:8-20.

25 Mesulam M, Geula C: Butylcholinesterase reactivity differentiates the amyloid plaques of aging from those of dementia. Ann Neurol 1994;36:722-727.

26 Khaw KY, Choi SB, Tan SC, Wahab HA, Chan KL, Murugaiyah V: Prenylated xanthones from mangosteen as promising cholinesterase inhibitors and their molecular docking studies. Phytomedicine 2014;21:13031309.

27 Giacobini E: Cholinesterase inhibitors: new roles and therapeutic alternatives. Pharmacol Res 2014;50:433-440.

28 Cokugras AN: Butyrylcholinesterase: structure and physiological importance. Turk J Biochem 2003;28:5461.

29 Zhan ZJ, Yu Q Wang ZL, Shan WG: Indole alkaloids from Ervatamia hainanensis with potent acetylcholinesterase inhibition activities. Bioorg Med ChemLett 2010;20:6185-6187. 